\title{
A critical and comparative study of methods of isolating tumour cells from the blood ${ }^{1}$
}

\author{
J. A. FLEMING AND J. W. STEWART \\ From the Bland-Sutton Institute of Pathology and Department of Surgical Studies, \\ Middlesex Hospital Medical School, London
}

SYNOPSIS From the large number of techniques described for isolating tumour cells from the blood, five have been selected because they were those most widely used by previous workers and can be performed with a minimum of special apparatus. These techniques have been assessed for their efficiency in retaining tumour cells added to blood samples, in eliminating normal blood cells, and in preserving the morphology of the retained cells.

Those techniques which depend on the differing densities of blood and tumour cells were reliable in recovering tumour cells unaltered morphologically and at the same time eliminating most of the blood cells. Because of its simplicity the silicone flotation technique has been preferred for routine use.

It has been known for 100 years that tumour cells sometimes enter the blood stream and occasional reports have recorded the finding of tumour cells in smears of capillary blood obtained by finger prick (Finkel and Tishkoff, 1960). However, in view of the small number of tumour cells present compared with the red and white blood cells, the chances against such a finding are very great indeed. Generally speaking, in order to demonstrate tumour cells in the circulating blood it is necessary to eliminate the greater part of the normal blood cells, and many techniques have been devised for doing this. Such a technique, in order to be satisfactory, must also retain tumour cells with normal morphology and staining characteristics.

The purpose of the present investigation was to compare the efficiency of the techniques which have most often been employed by workers in this field and to determine which of them was most suitable for routine use.

\section{PLAN OF THE STUDY}

Each technique studied has been assessed for its ability to eliminate normal blood cells, to retain tumour cells, and to minimize damage to tumour cells and retain their staining characteristics unaltered.

\footnotetext{
${ }^{1}$ The work presented in this paper formed part of a thesis for the degree of M.S. (London). It was also presented to a meeting of the Surgical Research Society in November 1962.
}

Received for publication 31 May 1966.
For this purpose the following experiments were performed:

ASSESSMENT OF ELIMINATION OF WHITE BLOOD CELLS A white cell count was performed on a specimen of blood from a volunteer subject, and the total number of cells in a given volume (usually $5 \mathrm{ml}$.) was calculated. This volume of blood was then processed by the technique being studied. A white cell count was performed on the resulting specimen and the total number of cells present in the specimen was calculated. This number, expressed as a percentage of the number of cells originally present, was called the 'percentage recovery of white cells'.

ASSESSMENT OF ELIMINATION OF RED CELLS In most of the techniques studied the red cells are completely eliminated. However, in the sedimentation techniques a small number was retained, and in three experiments the percentage recovery of red cells by these techniques has been estimated.

ASSESSMENT OF RETENTION OF TUMOUR CELLS For this $\mathrm{HeLa}$ cells were used. They were selected because they were human in origin, readily obtainable, and because they were large and easily distinguished from normal blood cells.

A bottle containing a monolayer culture of $\mathrm{HeLa}$ cells was shaken vigorously to obtain an even suspension of cells in the culture medium. A small quantity of the cell suspension was added to blood from a volunteer subject and mixed thoroughly. A 
HeLa cell count was performed and the total number of HeLa cells in a given volume (usually $5 \mathrm{ml}$.) was calculated. This volume was processed by the technique being studied. A HeLa cell count was performed on the processed specimen and the total number of cells present in the specimen was calculated. This number, expressed as a percentage of the number of cells originally present, was called the percentage recovery of HeLa cells.

ASSESSMENT OF PRESERVATION OF CELL MORPHOLOGY AND STAINING CHARACTERISTICS Blood, to which HeLa cells in suspension had been added, was processed by the technique under investigation. The cell suspension remaining after processing was centrifuged in a conical centrifuge tube for 15 minutes at $380 \mathrm{~g}$. The supernatant fluid was aspirated and the cellular deposit resuspended in the drop of fluid remaining in the tube. This material was smeared on slides and allowed to dry. When dry, the smears were fixed and stained by the MayGrunwald-Giemsa technique before being examined.

\section{METHODS AND RESULTS}

Four groups of techniques have been investigated.

GROUP 1: TECHNIQUES USING LYTIC AGENTS TO DESTROY SOME OF THE NORMAL BLOOD CELLS These techniques are the simplest of all, and were used by most of the early workers in this field. Saponin and acetic acid were the agents most commonly used, but both of these cause some damage to leucocytes and tumour cells. In an attempt to find a substance with selective lytic activity, Malmgren, Pruitt, del Vecchio, and Potter (1958) recommended the use of streptolysin-O, an enzyme produced by the haemolytic streptococcus. Although normally acting anaerobically the enzyme is capable of aerobic action in very high concentration. It destroys red cells and polymorphs, leaving lymphocytes, monocytes, and tumour cells intact.

Streptolysin- $O$ technique The method of Malmgren et al. (1958) was studied with the following minor modifications: $5.0 \mathrm{ml}$. of blood was used instead of $20 \mathrm{ml}$., with a corresponding reduction in the quantity of streptolysin-O. The initial centrifugation, which in the original description was at $300 \mathrm{~g}$ for 25 minutes, was at $700 \mathrm{~g}$ for 15 minutes.

In six experiments the average recovery was $72 \%$ (range $52 \%-83 \%$ ), the majority of these cells being lymphocytes. Red cells were completely eliminated by this technique. In six experiments the average recovery of tumour cells was $103 \%$ (range $77 \%$ $115 \%$ ).

HeLa cells processed in this way show signs of damage. The cytoplasm was vacuolated and the cell membrane damaged, and little intranuclear detail was visible. In addition, large masses of amorphous debris from the lysed red cells and polymorphs were present on the slides.

GROUP 2: TECHNIQUES ELIMINATING RED CELLS BY INCREASING SEDIMENTATION RATE In 1948, Minor and Burnett succeeded in extracting living leucocytes from whole blood by adding bovine fibrinogen and thereby increasing the rate of erythrocyte sedimentation; in 1957 Sandberg and Moore adapted this technique to the isolation of tumour cells from blood. Other workers (e.g., Alexander and Spriggs, 1960) have used dextran for the same purpose.

Methods using fibrinogen and dextran The techniques studied were those described by Skoog and Beck (1956). Both fibrinogen and dextran were used throughout as a $6 \%$ solution in physiological saline, except in two experiments with dextran, in which a $3 \%$ solution was used.

Six experiments with each substance yielded an average recovery of white cells of $95 \%$ (range $85 \%$ $102 \%$ ) with fibrinogen and of $78 \%$ (range $69 \%$ $84 \%$ ) with dextran. From three experiments with each substance the average recovery of red cells was $0.8 \%$ (range $0.6 \%-0.95 \%$ ) with fibrinogen and $3.4 \%$ (range $2.7 \%-4.5 \%$ ) with dextran.

In six experiments with fibrinogen and eight with dextran, the average recovery figures for tumour cells were: for fibrinogen $100 \%$ (range $75 \%-126 \%$ ) and for dextran $77 \%$ (range $64 \%-93 \%$ ).

The morphology and staining characteristics were identical with either fibrinogen or dextran. Figure 1 shows part of a slide prepared by fibrinogen sedimentation. The HeLa cells are clearly seen and have a well-defined cell boundary. Nuclear detail is visible and several nucleoli can be seen. The morphology of the leucocytes is similar to that observed in an ordinary blood film.

GROUP 3: TECHNIQUES ELIMINATING POLYMORPHONUCLEAR LEUCOCYTES BY UTILIZING THEIR PHAGOCYTIC ABILITY In 1934 Rous and Beard perfused the liver of a rat which had previously been injected with a suspension of particulate iron. By applying an electromagnet to the perfusate they were able to collect the reticuloendothelial cells which had ingested the iron. In 1961, Kuper, Bignall, and Luckcock first described an application of this principle to the study of circulating tumour cells. In their ingenious technique the polymorphs were eliminated in this way and the red cells destroyed with saponin. The resulting suspension therefore contained lymphocytes, monocytes, and tumour cells. 


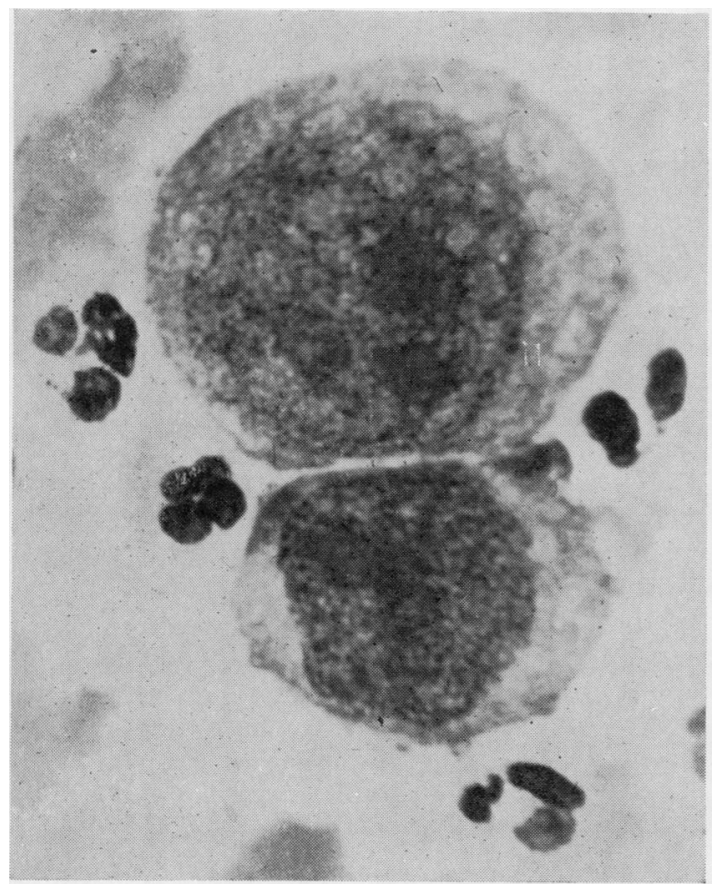

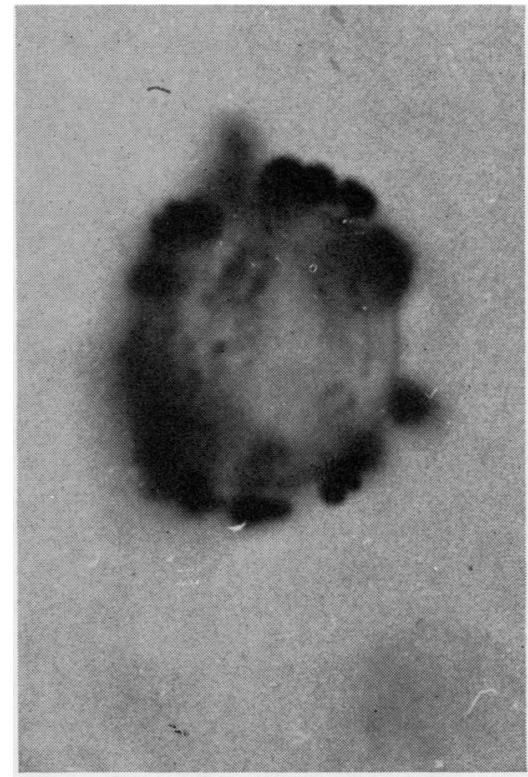

FIG. 2.

FIG. 1 .

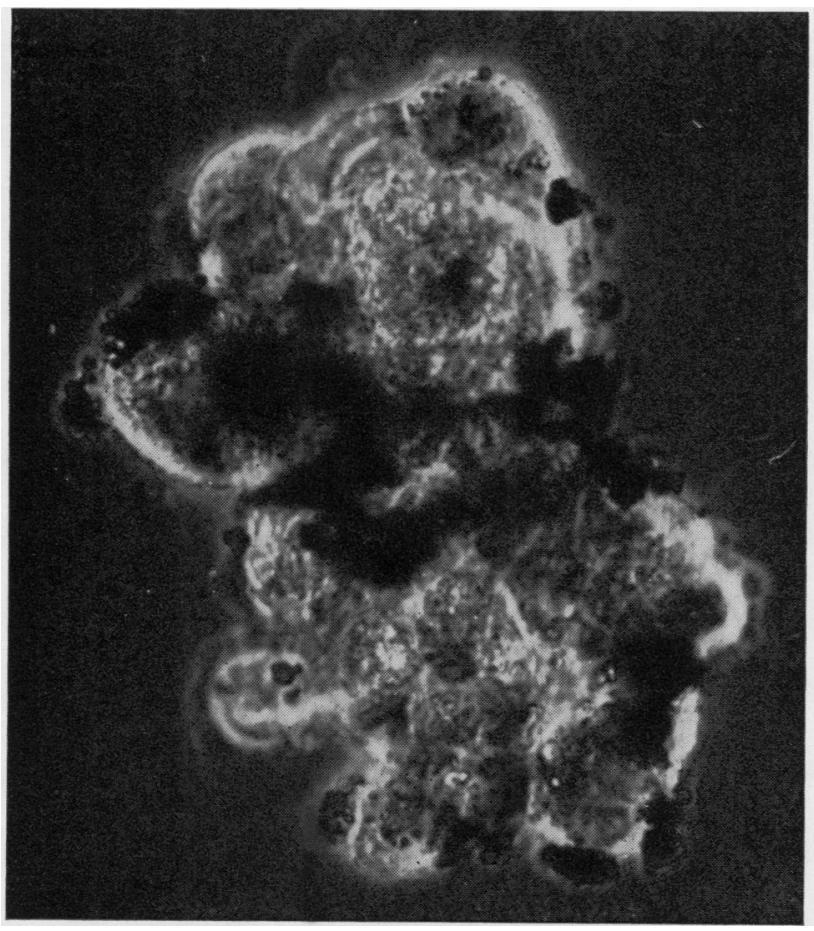

FIG. 1. Two HeLa cells and some blood cells from a slide prepared by fibrinogen sedimentation. Cellular architecture is excellently preserved and intranuclear detail is clearly seen $(\times 1,625)$.

FIG. 2. A single HeLa cell with adhering particles of carbonyl iron ( $\times 1,000$ approx.).

FIG. 3. A clump of HeLa cells with particles of carbonyl iron adherent to them (phase-contrast photomicrograph $\times 800$ approx.).

FIG. 3 . 
Iron ingestion technique The technique studied was that described by Kuper et al. (1961). Very much less saponin was used than they described.

In six experiments the average recovery of white cells was $50 \%$ (range $38 \%-55 \%$ ). Very few of the white cells remaining after processing were polymorphs. Red cells were completely eliminated by this technique. In six experiments the recovery figure for tumour cells ranged between $46 \%$ and $107 \%$, and the reason for this finding was sought by the following technique:

Carbonyl iron was added to a suspension of $\mathrm{HeLa}$ cells in physiological saline which was then incubated at $37^{\circ} \mathrm{C}$. for 30 minutes. A drop of the resulting suspension was placed in the well of a hollowed-out microscope slide, and covered with a coverslip which was sealed in position. The slide was then inverted and incubated for a further 30 minutes, during which time the HeLa cells sank on to the coverslip and became adherent to it. The slide was then turned right way up, any debris and loose iron particles allowed to fall away, and the under surface of the coverslip was examined by direct light and phase-contact microscopy.
Figure 2 shows a single HeLa cell, and Fig. 3 a clump of cells, prepared by this technique. Many iron particles can be seen to be adherent to the cells, although they do not appear to have been ingested by them; the method used precluded the possibility that these particles are merely resting in contact with the HeLa cells.

It is suggested that HeLa cells in blood become similarly coated with iron particles when this technique is used, and that some of these cells are removed when a magnet is introduced into the blood. This may explain the occasional low recovery of tumour cells.

The saponin used in this technique and the mechanical trauma of stirring with the magnet cause some damage to the cells but staining characteristics were fairly well preserved.

GROUP 4: TECHNIQUES SEPARATING BLOOD AND TUMOUR CELLS BY THEIR DIFFERENT DENSITIES The specific gravity of blood cells has been estimated by several workers, and their findings are summarized in Table $I$ and illustrated in Figure 4.

Separation of the less dense from the more dense

TABLE I

SPECIFIC GRAVITY OF BLOOD AND TUMOUR CELLS

\begin{tabular}{|c|c|c|c|c|c|}
\hline \multirow[b]{2}{*}{ Series } & \multirow[b]{2}{*}{ Platelets } & \multicolumn{2}{|l|}{ Leucocytes } & \multirow[b]{2}{*}{ Red Cells } & \multirow[b]{2}{*}{ Tumour Cells } \\
\hline & & Lymphocytes & Polymorphs & & \\
\hline $\begin{array}{l}\text { Pfeiffer (1897) } \\
\text { Fåhraeus (1921) } \\
\text { Reznikoff (1923) } \\
\text { Bodansky (1938) }\end{array}$ & & & & $\begin{array}{c}1.094 \\
1.091-1.097 \\
1.092-1.095 \\
1.090\end{array}$ & \\
\hline Vallee, Hughes, and Gibson (1947) & & & 080 & $1 \cdot 090$ & \\
\hline $\begin{array}{l}\text { Tullis (1952) } \\
\text { Seal (1959) } \\
\text { Spriggs and Boddington (1960) } \\
\text { Wintrobe (1961) } \\
\text { Powell (1962) }\end{array}$ & $\begin{array}{l}1.030 \\
1.032\end{array}$ & $\begin{array}{c}<1.075 \\
1.060-1.080\end{array}$ & $\begin{array}{l}51.075 \\
>1.075\end{array}$ & $\begin{array}{c}1.092 \\
1.092-1.097 \\
1.092-1095 \\
1.079-1.089\end{array}$ & $\begin{array}{c}1.056 \\
1.040-1.080 \\
<1.079\end{array}$ \\
\hline
\end{tabular}

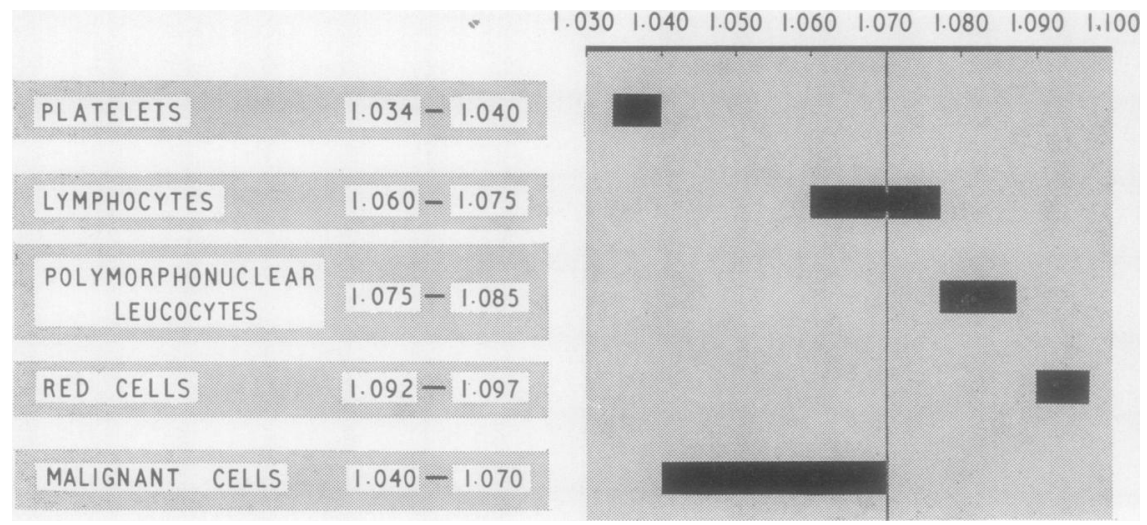

FIG. 4. A graphical representation of the specific gravities of blood and tumour cells. The solid blocks indicate the range of the specific gravity of each type of cell. A vertical line has been drawn to show the separation of cells obtainable by using $a$ fluid of S.G. 1.070. 


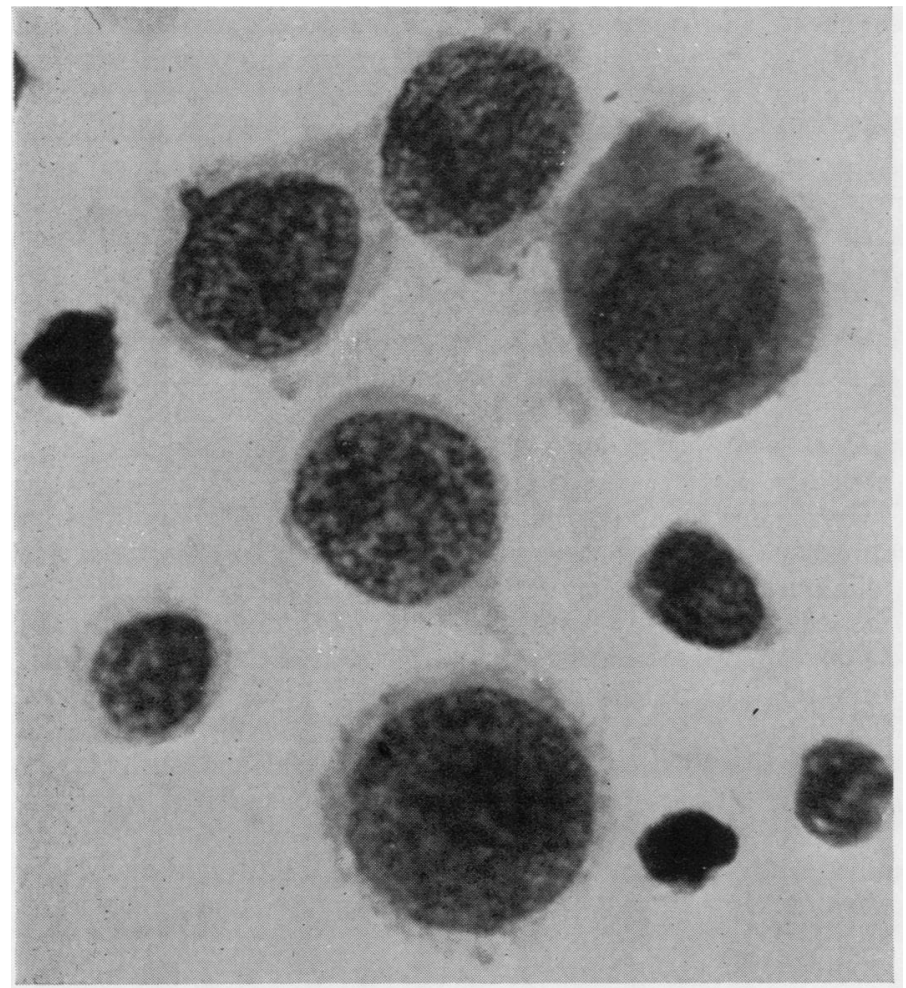

FIG. 5. Five HeLa cells and some monocytes and lymphocytes from a slide prepared by the silicone flotation technique. The cytoplasm is slightly fragmented but the nuclear membrane is quite intact and intranuclear detail is clearly visible. The 'background' of platelets usually present when this technique is used is not seen in the photograph $(\times 1,625)$.

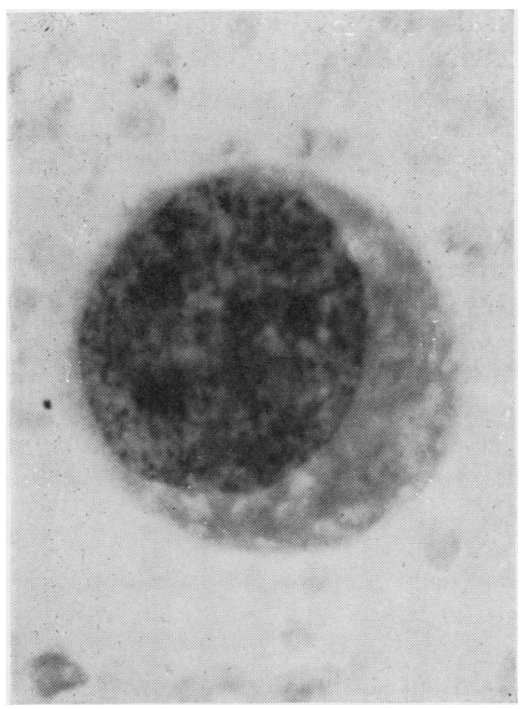

FIG. 6. $A$ single $\mathrm{HeLa}$ cell from $a$ slide prepared by the

albumin gradient technique. Nuclear and cytoplasmic architecture is well preserved and intranuclear detail is clearly visible. A 'background' of platelets is present $(\times 1,625)$. elements of the blood can be effected by layering the blood on a fluid of known specific gravity followed by rapid centrifugation. The separation obtainable by the use of a fluid of specific gravity of 1.070 is shown in Figure 4.

Early workers in this field used a concentrated solution of bovine serum albumin, but in 1959 Seal described the use of silicone fluid as an alternative, and, as this has now superseded albumin, it has been studied in this investigation. In 1960, Spriggs and Alexander described an albumin gradient method for separating tumour cells from blood, and this has also been investigated.

Silicone flotation The method studied was that of Seal (1959) modified so that the specific gravity of the silicone fluid was 1.070 and not 1.075 as originally described, and centrifugation was at 2,000 r.p.m. $(700 \mathrm{~g})$ and not at 1,500 r.p.m.

In eight experiments the average recovery of white blood cells was $41 \%$ (range $22 \%-52 \%$ ); most of them were lymphocytes. Red cells are completely eliminated by this technique.

The average recovery of tumour cells from 12 experiments was $103 \%$ (range $87 \%-116 \%$ ). Two further experiments were carried out in an attempt to discover whether the technique was as efficient in 
retaining small numbers of tumour cells as in retaining large numbers.

A dilute suspension of $\mathrm{HeLa}$ cells was made up containing between 100 and 200 cells in $0.1 \mathrm{ml}$. This volume was then added to a specimen of normal blood which, after thorough mixing, was processed. The deposit was smeared on slides which, after fixing and staining, were examined microscopically, all $\mathrm{HeLa}$ cells being counted. Recovery figures of $70 \%$ and $79 \%$ were obtained.

Figure 5 shows a clump of five HeLa cells and several lymphocytes from a slide prepared by this technique. The HeLa cells are slightly more darkly stained than usual, but the nuclear detail is clearly seen. The cytoplasm of the lymphocytes is slightly fragmented and their nuclei fairly densely stained.

Albumin gradient technique The technique studied was that described by Spriggs and Alexander (1960).

In six experiments the average recovery of white blood cells was $14 \%$ (range $1 \%-29 \%$ ). Red cells were completely eliminated.

In six experiments the average recovery of tumour cells was $95 \%$ (range $88 \%-105 \%$ ).

Figure 6 shows a single HeLa cell surrounded by platelets from a slide prepared by this technique. Morphology and staining characteristics are identical with those in the unprocessed specimen.

\section{DISCUSSION}

The essential features of a satisfactory technique for isolating tumour cells from the blood have already been outlined. By far the most important property that such a technique should possess is the ability to retain all tumour cells present.

In the present study this property has been investigated in detail. All the techniques studied, with the exception of the dextran sedimentation and iron ingestion techniques, are adequate in this respect. The iron ingestion technique has resulted in the loss of an appreciable number of tumour cells in our tests.

The two experiments with the silicone flotation technique, designed to determine its ability to retain small numbers of tumour cells as successfully as larger numbers, yielded recoveries of $70 \%$ and $79 \%$. These results are at first sight disappointing, but in the experiment no cell was counted unless it could be positively identified as a HeLa cell. This meant that a number of slightly damaged cells, for example, those in the 'tailings' of smears, were not included in the count. In the circumstances the recovery figures obtained may well represent the highest recovery possible.

The second most important property which should be possessed by a satisfactory technique is that of preserving unaltered the morphology and staining characteristics of the retained cells. In this respect the sedimentation and albumin gradient techniques are outstanding, and the silicone flotation and iron ingestion techniques are adequate. The streptolysin$O$ technique damages the cells and alters their staining characteristics, at the same time producing a large amount of debris, which hinders rapid scanning and may obscure tumour cells.

The ability of a technique to eliminate normal blood cells is of less theoretical importance than the other two properties which have just been discussed, but is of considerable practical importance, as the ease and rapidity of scanning a specimen, always a time-consuming process, depend to a large extent on it. The only techniques which do not cause complete removal of red cells from the specimen are those which depend on sedimentation. In these, although the proportion of red cells retained is low $(0.8 \%$ with fibrinogen, $3.4 \%$ with dextran), the actual numbers of cells retained are fairly large. Their presence increases the bulk of the specimen and thereby prolongs the scanning time required.

The most complete removal of white cells is produced by the albumin gradient technique; the silicone flotation and iron ingestion techniques remove about half the white cells, and the streptolysin-O technique removes about a third.

It appears that the albumin gradient technique possesses all the required properties. There is, however, one factor which must be considered: platelet aggregation must be avoided for the satisfactory separation of the white cell concentrate into its various layers. If platelets clump, the layers may either not be formed at all, or, when formed, may be incompletely separated from one another. Three precautions must be taken. (1) E.D.T.A. must be used as an anticoagulant. (2) All glassware, including Pasteur pipettes, must be siliconed. (3) Dextran, not fibrinogen, must be used for the preliminary sedimentation, as fibrinogen invariably causes some aggregation of platelets.

The first two of these precautions do not constitute drawbacks to the technique, but the fact that dextran and not fibrinogen must be used for sedimentation is a disadvantage, because, with dextran, it is not possible to recover all the tumour cells present in a single sedimentation process.

The silcone flotation technique is reliable in retaining all tumour cells present and in eliminating the great majority of white cells. Although saponin is used to destroy the small number of red cells remaining after centrifugation, the morphology of the cells in the resulting specimens is satisfactory. The technique is, moreover, easy to perform and 
gives good results even when the conditions are less than ideal, e.g., if the blood sample has erroneously been supplied in an unsiliconed tube with heparin as anticoagulant. For this reason it is regarded as the most suitable for routine use, and has been used as described elsewhere (Fleming, 1963) for the study of circulating tumour cells.

This work was carried out while one of us (J.A.F.) was receiving a grant from the Medical Research Council.

It is a pleasure to acknowledge the help of Mr. D. H. Patey, formerly Director of the Department of Surgical Studies, Middlesex Hospital, who instigated the study and gave constant advice and encouragement; Dr. M. A. Epstein, who arranged for a supply of $\mathrm{HeLa}$ cells, and devised the experiment to discover the reason for the loss of these cells by the iron ingestion technique; and Miss Joan Thurn and Mr. N. F. Robinson.

\section{REFERENCES}

Alexander, R. F., and Spriggs, A. I. (1960). J. clin. Path., 13, 414.
Bodansky, M. (1938). Introduction to Physiological Chemistry, 4th ed., p. 221. Wiley, New York.

Fåhraeus, R. (1921). Acta med. scand., 55, 114.

Finkel, G. C., and Tishkoff, G. H. (1960). New Engl. J. Med., 262, 187.

Fleming, J. A. (1963). Proc. roy. Soc. Med., 56, 497.

Kuper, S. W. A., Bignall, J. R., and Luckcock, E. D. (1961). Lancet, 1, 852.

Malmgren, R. A., Pruitt, J. C., del Vecchio, P. R., and Potter, J. F. (1958). J. nat. Cancer Inst., 20, 1203.

Minor, A. H., and Burnett, L. (1948). Blood, 3, 799.

Pfeiffer, T. (1897). Z. klin, Med., 33, 215.

Powell, M. E. A. (1962). Nature (Lond.), 193, 1047.

Reznikoff, P. (1923). J. exp. Med., 38, 441.

Rous, P., and Beard, J. W. (1934). Ibid., 59, 577.

Sandberg, A. A., and Moore, G. E. (1957). J. nat. Cancer Inst., 19, 1. Seal, S. H. (1959). Cancer (Philad.), 12, 590.

Skoog, W. A., and Beck, W. S. (1956). Blood, 11, 436,

Spriggs, A. I., and Alexander, R. F. (1960). Nature (Lond.), 188, 863. , and Boddington, M. M. (1960). A.R. Brit. Emp. Cancer Campgn., $38,414$.

Tullis, J. L. (1952). Blood, 7, 891.

Vallee, B. L., Hughes, W. L. Jr., and Gibson, J. G. (1947). Ibid, Special Issue, 1, 82.

Wintrobe, M. M. (1961). Clinical Haematology, 5th ed., p. 323. Kimpton, London. 